\title{
ANALISIS KEPUASAN MAHASISWA TERHADAP WEBSITE UNIVERSITAS FLORES
}

\author{
Anastasia Mude ${ }^{1}$, Kristina Sara ${ }^{2}$, Ferdinandus Lidang Witi ${ }^{3}$ \\ ${ }^{1,2,3}$ Program Studi Sistem Informasi, Fakultas Teknologi Informasi, Universitas Flores \\ Jl. Sam Ratulangi, Kelurahan Paupire, Kecamatan Ende Tengah \\ Kabupaten Ende - Nusa Tenggara Timur \\ E-mail : annmude87@gmail.com ${ }^{1}$, kristinasara27@gmail.com ${ }^{2)}$, ferdylidang2017@gmail.com ${ }^{3)}$
}

\begin{abstract}
A website in a university is a media for providing or sharing information about the university's activity to academics. So it is with the website of Flores University, that always provides information for many people. The providing Information in the website, still gets complaints from students accessing the website, so a research is conducted to determine the student's satisfaction level in accessing the website. The satisfaction measurement of WebQual method 4.0 was used. Some reviewed aspects were usability, information quality, and service interaction. This research was done by having 100 students of Flores University as the respondents. The technique of data collection was by giving questionnaire. The result for usability aspect was having a positive influence and significant towards students' satisfaction. A website that is easy to use and has a attractive appearance, makes the students feel relieve in accessing. While for the aspect of information quality and service interaction did not influence the students' satisfaction. It means that the university must provide the information qualities and the service interactions that are up to date, so the students will gladly access the website.
\end{abstract}

Keyword-Student's satisfaction, website, WebQual 4.0

\begin{abstract}
ABSTRAK
Website dari suatu perguruan tinggi merupakan wadah untuk menyampaikan informasi tentang kegiatan-kegiatan bagi warga kampus. Begitupula dengan website yang ada di Universitas Flores, yang selama ini sudah memberikan informasi kepada khayalak banyak. Informasi yang diberikan masih ditemukan beberapa keluhan dari mahasiswa. Keluhan yang didapat seperti tampilan yang kurang menarik dan penyampaian informasi yang tidak cepat. Penelitian ini bertujuan untuk mengetahui tingkat kepuasan mahasiswa dalam mengakses website. Pengukuran kepuasan menggunakan metode WebQual 4.0. Aspek yang ditinjau berupa usability, information quality dan service interaction. Penelitian dilakukan pada mahasiswa Fakultas Teknologi Informasi Universitas Flores sebanyak 100 responden. Pengumpulan data dengan cara memberikan kuesioner. Hasil yang diperoleh dari aspek usability, mempunyai pengaruh yang positif dan signifikan terhadap kepuasan mahasiswa. Website yang mudah digunakan dan tampilan yang menarik, membuat mahasiswa merasa senang untuk mengaksesnya. Sedangkan aspek information quality dan service interaction tidak berpengaruh terhadap kepuasan mahasiswa. Yang berarti bahwa pihak kampus harus menyiapkan kualitas informasi dan interaksi layanan yang up to date, sehingga nantinya mahasiswa senang untuk mengakses website tersebut.
\end{abstract}

Kata Kunci - kepuasan mahasiswa, website, WebQual 4.0 


\section{Pendahuluan}

Pada era globalisasi saat ini, tidak dapat dipungkiri perkembangan teknologi dan informasi terjadi begitu cepat. Manfaat dari perkembangan teknologi dan informasi juga bisa di rasakan oleh semua orang dalam berbagai bidang, termasuk bidang pendidikan. Akses informasi menjadi sangat mudah dan bisa dilakukan kapan dan di mana saja dengan adanya jaringan internet, sehingga di mungkinkan terjadi konektivitas dengan semua penyelenggara pendidikan baik di tingkat operasional sampai ke tingkat pengambil kebijakan.

Universitas Flores merupakan salah satu perguruan tinggi di Flores Nusa Tenggara Timur yang memiliki visi sebagai mediator budaya. Oleh karena itu Universitas Flores harus pula menjadi media penyampaian informasi yang mampu menjembatani wujud-wujud budaya menyangkut nilai, gagasan dan hasil karya daya cipta manusia. Untuk menjembatani wujud-wujud budaya tersebut, informasi yang diberikan harus dapat dilakukan dengan cepat, tepat dan akurat. Media yang digunakan untuk menyampaikan informasi tersebut adalah website.

Website merupakan salah satu jenis media yang dipublikasi melalui jaringan internet yang dapat diakses dimanapun dan kapanpun [1]. Pengertian website juga diartikan sebagai keseluruhan halamanhalaman web yang terdapat dalam sebuah domain yang mengandung informasi [2]. Hal ini bisa disimpulkan bahwa dengan menyampaikan informasi melalui website, maka semua mahasiswa atau warga kampus bisa mendapatkan informasi tersebut kapan saja dan dimana saja.

Dalam penyampaian informasi di website perlu diperhatikan kecepatan akses dan keakuratan informasi, karena itu sangat berpengaruh pada kepuasan mahasiswa terhadap website. Kepuasan maupun ketidakpuasan mahasiswa dilihat saat mereka mendapatkan informasi yang dibutuhkan. Kepuasan merupakan perasaan senang yang timbul dari diri seseorang terhadap apa yang didapat dan dilihatnya. Kepuasan user merupakan elemen penting dalam menyediakan pelayanan yang lebih baik, lebih efisien dan lebih efektif [3]. Website dengan tampilan yang menarik, informasi yang benar dan tepat, dapat membuat seseorang merasa senang menggunakannya. Website merupakan representasi pemilik website di dunia maya, oleh karena itu pemilik website perlu memperhatikan kualitas, karena kualitas website dapat memberikan gambaran dari kualitas pemiliknya [4].

Metode yang digunakan untuk mengukur kualitas sebuah website adalah 
WebQual [5]. Metode ini merupakan pengembangan dari Servqual yang banyak digunakan sebelumnya pada pengukuran kualitas jasa [6]. Ada tiga dimensi dalam metode WebQual 4.0 [7].

1. Kualitas kegunaan (usability quality) yang mengutamakan pada kegunaan dari sebuah website. Dimensi ini berkaitan dengan rancangan website seperti tampilan website, kemudahan penggunaan, navigasi dan gambaran yang disampaikan kepada pengguna.

2. Kualitas informasi (information quality) yang mengutamakan pada kualitas atau mutu isi yang terdapat pada website.

3. Kualitas interaksi pelayanan (service interaction quality) yang mengutamakan pada kualitas atau mutu interaksi pelayanan terhadap pengguna.

Universitas Flores dengan laman http://uniflor.ac.id hadir sebagai alternatif penyedia informasi dan komunikasi yang cakap serta berguna sebagai perpanjangan tangan untuk menggapai lapisan masyarakat khususnya mahasiswa yang menggunakan teknologi internet dalam mencari informasi.

Fitur yang terdapat pada website antara lain; tentang uniflor, penerimaan mahasiswa baru, unit, fakultas, akademik, KRS online, beasiswa, data alumni, dan kalender akademik. Setelah melakukan penelitian pada mahasiswa ditemukan beberapa fitur yang sudah bisa diakses dan informasi yang dicari ditampilkan pada fitur tersebut. Fiturnya antara lain; tentang uniflor, penerimaan mahasiswa baru, unit, fakultas, dan akademik.

Fitur KRS online, kadang sulit atau tidak bisa diakses dari luas kampus. Fitur kalender akademik yang tidak update sesuai dengan semester yang berjalan. Fitur beasiswa dan data alumni belum menampilkan informasi. Itu semua yang mengakibatkan mahasiswa merasa tidak puas dalam mengakses website.

\section{Metode Penelitian}

\subsection{Metode Penelitian}

Metode penelitian yang digunakan dalam penelitian ini adalah metode penelitian kuantitatif. Metode kuantitatif adalah penelitian yang datanya berupa angka-angka dan analisis menggunakan statistik [8].

\section{2. Populasi dan Sampel}

Populasi adalah wilayah generalisasi yang terdiri atas obyek/subyek yang mempunyai kualitas dan karakteristik tertentu yang ditetapkan peneliti untuk dipelajari [8]. Populasi diambil dari mahasiswa Fakultas Teknologi Informasi yang berjumlah 113 orang. Pengambilan sampel menggunakan rumus Slovin. Sehingga diperoleh sampel sebanyak 100 . 
Pengumpulan data menggunakan kuesioner, dengan skala likert.

\subsection{Uji Instrumen}

Uji validitas menggunakan uji validitas product momen pearson correlation untuk menghubungkan antara masing-masing skor item dengan total skor. Instrumen yang valid berarti instrumen tersebut dapat digunakan untuk mengukur apa yang seharusnya diukur [8]. Pengujian statistik mengacu pada kriteria sebagai berikut:

- $\quad r$ hitung $<\mathrm{r}$ tabel maka tidak valid

- $\quad r$ hitung>r tabel maka valid

Selain dilakukan uji validitas, juga dilakukan uji reliabilitas. Reabilitas itu berhubungan dengan masalah kepercayaan [9]. Suatu tes dapat dikatakan mempunyai taraf kepercayaan yang tinggi jika tes tersebut dapat memberikan hasil yang tetap. Uji reliabilitas dilakukan dengan menggunakan Statistical Product and Service Solution (SPSS) 22 for windows. [10]. Item dikatakan reliabel jika nilai Cronbach"s Alpha lebih besar dari nilai kritis. Nilai kritis yang ditetapkan adalah 0,6 .

- Jika nilai Alpha>0,6 maka reliabel

- Jika nilai Alpha<0,6 maka tidak reliabel

\subsection{Teknik Analisis Data}

Dalam penelitian ini menggunakan teknik analisis data korelasi pearson product moment dan korelasi ganda. Yang di uji antara lain: Uji asumsi klasik, Uji F dan Uji T.

\subsubsection{Uji Asumsi Klasik}

Uji Asumsi Klasik terdiri dari: Multikolinearitas, Heterokedastisitas, Autokorelasi dan Normalitas data. Yang mana penggunaannya untuk melakukan analisis regresi.

a. Uji Normalitas Data

Normalitas data digunakan untuk mengetahui apakah data terdistribusi dengan normal atau tidak. Uji normalitas data menggunakan Kolmogorov-Smirnov dengan SPSS.

b. Uji Multikolinearitas

Untuk mengetahui terjadi atau tidaknya multikolinearitas dengan melihat hasil nilai tolerance dan VIF. Semakin kecil nilai tolerance dan semakin besar nilai VIF, maka mendekati terjadinya masalah multikolinearitas. Nilai tolerance lebih dari 0,1 dan VIF kurang dari 10, maka terjadi multikolinearitas.

c. Uji Heterokedastisitas

Heterokedastisitas digunakan untuk mengkorelasi nilai residu hasil regresi dengan masing-masing variabel independen dan variabel dependen dengan menggunakan Scatterplot. 


\section{d. Uji Autokorelasi}

Autokorelasi digunakan untuk mengetahui terjadinya korelasi dari residual dengan cara pengamatan satu dengan yang lain menurut urutan waktu.

\section{e. Uji Linieritas}

Uji linieritas digunakan untuk mengetahui apakah dua variabel mempunyai hubungan yang linier secara signifikan atau tidak.

\subsubsection{Uji Koefisien Kolerasi dan} koefisien determinasi

Uji koefisien korelasi dan koefisien determinasi digunakan untuk mengetahui tingkat keeratan hubungan yang dimiliki antar variabel dalam penelitian.

\subsubsection{Uji F dan Uji T}

Uji $F$ digunakan untuk menguji pengaruh variabel independen secara simultan terhadap variabel dependen. Uji $\mathrm{T}$ digunakan untuk menguji pengaruh variabel independen secara parsial terhadap variabel dependen.

\section{Hasil Dan PEMbahasan}

\subsection{Hasil Penelitian}

\subsubsection{Hasil Uji Instrumen}

a. Hasil Uji Validitas

Pada penelitian ini nilai rtabel dengan $\mathrm{n}=$ 100 maka didapat rtabel sebesar 0,195, jadi apabila rhitung>rtabel maka dinyatakan valid.

Tabel 1. Hasil Uji Validitas

\begin{tabular}{|c|c|c|c|}
\hline $\begin{array}{c}\text { No } \\
\text { Item }\end{array}$ & rhitung & rtabel & Keterangan \\
\hline
\end{tabular}

\begin{tabular}{|c|c|c|c|}
\hline X1.1 & 0,658 & 0,195 & Valid \\
\hline X1.2 & 0,667 & 0,195 & Valid \\
\hline X1.3 & 0,741 & 0,195 & Valid \\
\hline X1.4 & 0,711 & 0,195 & Valid \\
\hline X1.5 & 0,765 & 0,195 & Valid \\
\hline X1.6 & 0,624 & 0,195 & Valid \\
\hline X1.7 & 0,702 & 0,195 & Valid \\
\hline X2.1 & 0,658 & 0,195 & Valid \\
\hline X2.2 & 0,659 & 0,195 & Valid \\
\hline X2.3 & 0,722 & 0,195 & Valid \\
\hline X2.4 & 0,692 & 0,195 & Valid \\
\hline X2.5 & 0,739 & 0,195 & Valid \\
\hline X2.6 & 0,688 & 0,195 & Valid \\
\hline X2.7 & 0,68 & 0,195 & Valid \\
\hline X3.1 & 0,684 & 0,195 & Valid \\
\hline X3.2 & 0,681 & 0,195 & Valid \\
\hline X3.3 & 0,736 & 0,195 & Valid \\
\hline X3.4 & 0,704 & 0,195 & Valid \\
\hline X3.5 & 0,734 & 0,195 & Valid \\
\hline X3.6 & 0,699 & 0,195 & Valid \\
\hline X3.7 & 0,685 & 0,195 & Valid \\
\hline Y.1 & 0,69 & 0,195 & Valid \\
\hline Y.2 & 0,658 & 0,195 & Valid \\
\hline Y.3 & 0,637 & 0,195 & Valid \\
\hline Y.4 & 0,669 & 0,195 & Valid \\
\hline Y.5 & 0,728 & 0,195 & Valid \\
\hline Y.6 & 0,612 & 0,195 & Valid \\
\hline Y.7 & 0,682 & 0,195 & Valid \\
\hline
\end{tabular}

b. Hasil Uji Reabilitas

Pengujian instrumen reabilitas menggunakan metode Cronbach Alpha. Hasil pengujian pada setiap varibel terlihat pada tabel 2 .

\section{Tabel 2. Hasil Uji Reabilitas}

\begin{tabular}{|l|c|l|}
\hline \multicolumn{1}{|c|}{ Variabel } & Cronbach's Alpha & Keterangan \\
\hline Usability & 0,821 & Reliabel \\
\hline $\begin{array}{l}\text { Information } \\
\text { Quality }\end{array}$ & 0,817 & Reliabel \\
\hline $\begin{array}{l}\text { Service } \\
\text { Interactioni }\end{array}$ & 0,829 & Reliabel \\
\hline $\begin{array}{l}\text { Kepuasan } \\
\text { Mahasiswa }\end{array}$ & 0,791 & Reliabel \\
\hline
\end{tabular}

\subsubsection{Uji Asumsi Klasik}

a. Hasil Uji Normalitas 
Uji normalitas data menggunakan Kolmogorov-Smirnov dengan SPSS. Nilai signifikansi Asiymp.Sig (2-tailed) sebesar 0,348>0,05. Dari hasil tersebut menunjukkan bahwa data berdistribusi normal dan sudah terpenuhi.

\section{Tabel 3. Hasil uji normalitas}

menggunakan Kolmogorov-

\section{Smirnov}

\begin{tabular}{|ll|r|}
\hline & & \multicolumn{2}{|c|}{$\begin{array}{c}\text { Unstandardized } \\
\text { Residual }\end{array}$} \\
\hline $\mathrm{N}$ & Mean & 100 \\
Normal & Std. & 1,6000000 \\
Parameters & Deviation &, 093 \\
& Absolute &, 089 \\
Most Extreme & Positive &,- 093 \\
Differences & Negative &, 933 \\
& Kolmogorov-Smirnov Z &, 348 \\
Asymp. Sig. (2-tailed) & \\
\hline
\end{tabular}

\section{b. Hasil Uji Multikolinearitas}

Uji multikolinearitas bertujuan untuk menguji ada tidaknya korelasi yang signifikan yang mendekati sempurna antar variabel independen. Hasil uji multikolinearitas tertuang pada tiap variabel tertuang pada tabel 4 .

Tabel 4. Hasil Uji Multikolinieritas

\begin{tabular}{|l|r|r|}
\hline \multicolumn{1}{|c|}{ Variabel } & Tolerance & \multicolumn{1}{c|}{ VIF } \\
\hline Usability & 0,370 & 2,701 \\
\hline Information Quality & 0,188 & 5,323 \\
\hline Service Interactioni & 0,183 & 5,456 \\
\hline
\end{tabular}

Berdasarkan tabel 4, hasil uji multikolinearitas yang didapat adalah nilai Tolerance seluruhnya lebih besar dari 0,1 dan nilai VIF seluruhnya lebih kecil dari 10, sehingga variabel usability $\left(\mathrm{X}_{1}\right)$, information quality $\left(\mathrm{X}_{2}\right)$ service interaction $\left(\mathrm{X}_{3}\right)$ tidak terjadi atau bebas dari gejala multikolinieritas.

c. Hasil Uji Heterokedastisitas

Uji heteroskedastisitas dilakukan dengan Scatterplot.

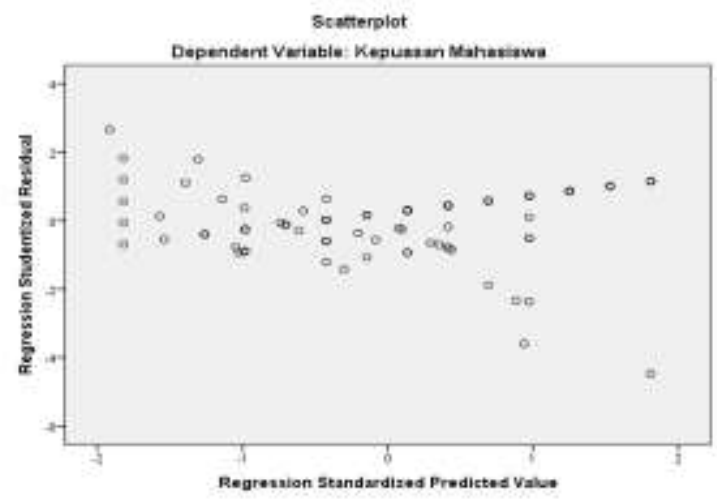

\section{Gambar 1. Hasil Uji Heteroskedastisitas}

Hasil pengujian heteroskedastisitas menunjukkan bahwa titik-titik tidak membentuk pola tertentu atau tidak ada pola yang jelas serta titik-titik menyebar di atas dan di bawah angka 0 (nol) pada sumbu Y, maka tidak terjadi heteroskedastisitas. Dengan demikian, asumsi-asumsi normalitas, multikolinearitas dan heteroskedastisitas dalam model regresi dapat dipenuhi dari model ini.

\section{d. Hasil Uji Autokorelasi}

Diperoleh nilai Durbin Watson (d) sebesar 2,086 lebih besar dari batas atas (du) yakni 1,736 dan kurang dari (4-du) 4$1,736=2.264$. Maka dapat disimpulkan bahwa tidak terjadi autokorelasi.

e. Hasil Uji Linieritas 
Setelah dilakukan uji linieritas terhadap ketiga variabel mendapatkan nilai signifikan sebesar $0,000<0,005$. Hasil ini berarti setiap variabel bersifat linier.

\subsubsection{Hasil Uji Koefisien Kolerasi dan} Koefisien Determinasi

Tabel 5 Hasil Uji Uji Koefisien Kolerasi dan Koefisien Determinasi

\begin{tabular}{l|c|c|c|r|}
\hline Model & $\mathrm{R}$ & R Square & $\begin{array}{c}\text { Adjusted R } \\
\text { Square }\end{array}$ & $\begin{array}{c}\text { Std. Error of } \\
\text { the Estimate }\end{array}$ \\
\hline 1 &, $865^{\mathrm{a}}$ &, 748 &, 740 & 1,634 \\
\hline
\end{tabular}
a. Predictors: (Constant), Service Interaction, Usability,
Information Quality

Berdasarkan hasil uji koefisien korelasi pada tabel 5, diketahui nilai correlation coefficient sebesar 0.865. Hasil tersebut berarti menunjukkan hubungan yang sangat kuat antara kepuasan pengguna dengan usability, information quality, dan service interaction.

Sedangkan koefisien determinasi hasilnya sebesar $=0,748$. Artinya variabel usability $\left(\mathrm{X}_{1}\right)$, information quality $\left(\mathrm{X}_{2}\right)$ service interaction $\left(\mathrm{X}_{3}\right)$ dapat menerangkan atau menjelaskan kepuasan pengguna (Y) sebesar 74,8\%, $(0.748 \mathrm{X}$ $100 \%$ ) sisanya sebesar $25,2 \%$ dipengaruhi oleh variabel lain yang tidak termasuk dalam model atau persamaan pada penelitian ini.

\subsubsection{Hasil Uji F dan Uji T}

a. Hasil Uji F

\section{Tabel 6. Hasil Uji F}

\begin{tabular}{|c|c|c|c|c|c|}
\hline \multicolumn{6}{|c|}{ ANOVA $^{\mathrm{a}}$} \\
\hline Model & $\begin{array}{l}\text { Sum of } \\
\text { Squares }\end{array}$ & Df & $\begin{array}{c}\text { Mean } \\
\text { Square }\end{array}$ & $\mathrm{F}$ & Sig. \\
\hline 1 Regression & 759,749 & 3 & 253,250 & 94,861 &, $000^{\mathrm{b}}$ \\
\hline Residual & 256,291 & 96 & 2,670 & & \\
\hline Total & 1016,040 & 99 & & & \\
\hline
\end{tabular}

a. Dependent Variable: Kepuasan Mahasiswa

b. Predictors: (Constant), Service Interaction, Usability, Information Quality

Nilai signifikansi yang diperoleh $0,000<0,05$. Maka diartikan bahwa variabel usability $\left(\mathrm{X}_{1}\right)$, information quality $\left(\mathrm{X}_{2}\right)$ service interaction $\left(\mathrm{X}_{3}\right)$ secara simultan berpengaruh terhadap kepuasan mahasiswa (Y). Nilai $\mathrm{F}$ hitung yang diperoleh sebesar 94.861. Karena nilai $\mathrm{F}$ hitung 94.861>3,09 F tabel, maka hipotesis di terima. Artinya usability $\left(\mathrm{X}_{1}\right)$, information quality $\left(\mathrm{X}_{2}\right)$ service interaction $\left(\mathrm{X}_{3}\right)$ secara simultan berpengaruh terhadap kepuasan mahasiswa.

b. Hasil Uji T

\section{Tabel 7. Hasil Uji T}

\begin{tabular}{|c|c|c|c|c|c|c|}
\hline \multirow{2}{*}{\multicolumn{2}{|c|}{ Model }} & \multicolumn{2}{|c|}{$\begin{array}{c}\text { Unstandardi } \\
\text { zed } \\
\text { Coefficients }\end{array}$} & \multirow{2}{*}{$\begin{array}{c}\begin{array}{c}\text { Standa } \\
\text { rdized } \\
\text { Coeffic } \\
\text { ients }\end{array} \\
\text { Beta } \\
\end{array}$} & \multirow[t]{2}{*}{$\mathbf{T}$} & \multirow[t]{2}{*}{ Sig. } \\
\hline & & B & $\begin{array}{l}\text { Std. } \\
\text { Erro } \\
\quad r \\
\end{array}$ & & & \\
\hline \multirow[t]{4}{*}{1} & (Constant) & $\begin{array}{r}5,85 \\
3\end{array}$ & 1,355 & & 4,321 & $\overline{, 000}$ \\
\hline & Usability & ,605 & ,072 & ,710 & 8,446 & ,000 \\
\hline & $\begin{array}{l}\text { Informatio } \\
\text { n Quality }\end{array}$ &, 252 & ,198 &, 276 & 1,269 & ,207 \\
\hline & $\begin{array}{l}\text { Service } \\
\text { interaction }\end{array}$ & - &, 178 &,- 094 &,- 466 & ,642 \\
\hline
\end{tabular}

Berdasarkan tabel 7, variabel usability $\left(\mathrm{X}_{1}\right)$ mendapatkan nilai signifikansi 
sebesar 0,000. Karena nilai $0,000<0,05$, maka dapat disimpulkan bahwa $\mathrm{H}_{1}$ di terima. Artinya ada pengaruh positif secara parsial usability terhadap kepuasan mahasiswa. Nilai $\mathrm{t}$ hitung diperoleh sebesar 8,446. Karena nilai $t$ hitung $>t$ tabel 1,988. Maka dapat disimpulkan bahwa $\mathrm{H}_{1}$ di terima. Artinya ada pengaruh positif secara parsial usability terhadap kepuasan mahasiswa.

Variabel information quality $\left(\mathrm{X}_{2}\right)$ memperoleh nilai signifikansi sebesar 0,207. Karena nilai 0,207>0,05, maka dapat disimpulkan bahwa $\mathrm{H}_{2}$ di tolak. Artinya tidak ada pengaruh information quality terhadap kepuasan mahasiswa. Nilai $t$ hitung variabel kemudahan penggunaan diperoleh sebesar 1,269. Karena nilai $\mathrm{t}$ hitung $<\mathrm{t}$ tabel 1,988 . Maka dapat disimpulkan bahwa $\mathrm{H}_{1}$ di tolak. Artinya tidak ada pengaruh information quality terhadap kepuasan mahasiswa.

Variabel service interaction $\left(\mathrm{X}_{3}\right)$ memperoleh nilai signifikansi yang diperoleh sebesar 0,642. Karena nilai 0,642>0,05, maka dapat disimpulkan bahwa $\mathrm{H}_{3}$ di tolak. Artinya tidak ada pengaruh service interaction terhadap kepuasan mahasiswa. Nilai $t$ hitung variabel kemudahan penggunaan diperoleh sebesar -0,094. Karena nilai $t$ hitung $>t$ tabel 1,988. Maka dapat disimpulkan bahwa $\mathrm{H}_{1}$ di tolak. Artinya tidak ada pengaruh service interaction terhadap kepuasan mahasiswa.

\subsection{Pembahasan}

Hipotesis pertama memperoleh nilai signifikansi sebesar $0,000<0,05$, maka hipotesis ini diterima. Dan dilihat dari nilai F hitung sebesar 94.861>3,09 F tabel, maka hipotesis ini diterima. Hasil ini berarti bahwa usability $\left(\mathrm{X}_{1}\right)$, information quality $\left(\mathrm{X}_{2}\right)$ dan service interaction $\left(\mathrm{X}_{3}\right)$ secara simultan berpengaruh terhadap kepuasan mahasiswa (Y). Dalam hal ini apabila website Universitas Flores memiliki tampilan yang menarik, mudah di akses kapan saja oleh mahasiswa dengan up to date, maka akan meningkatkan kepuasaan mahasiswa terhadap website. Penelitian yang lain juga memberikan hasil yang sama, bahwa pengaruh usability, information quality, dan service interaction secara simultan memberikan dampak positif pada kepuasaan pelanggan [11].

Hipotesis kedua mendapatkan nilai signifikansi sebesar $0,000<0,05$, maka hipotesis ini diterima. Perolehan nilai $\mathrm{t}$ hitung 8,446>1,988 t tabel, maka hipotesis ini diterima. Bisa disimpulkan bahwa usability $\left(\mathrm{X}_{1}\right)$ secara parsial berpengaruh terhadap kepuasan mahasiswa (Y). Dalam 
hal ini website Universitas Flores sudah memiliki tampilan yang menarik, mudah digunakan atau mudah diakses. Dengan begitu mahasiswa merasa senang atau puas dalam mencari informasi yang dibutuhkannya. Penelitian yang lain juga memberikan hasil yang sama, bahwa usability secara parsial memiliki pengaruh positif terhadap tingkat kepuasaan pelanggan [11]. Kemudahan penggunaan website, desain interface website dan fitur yang ada pada website xyz dapat meningkatkan tingkat kepuasan pelanggan.

Hipotesis ketiga memperoleh nilai signifikansi $0,207>0,05$, maka hipotesis ini ditolak. Dan juga dilihat dari nilai $\mathrm{t}$ hitung $1,269<1,988 \mathrm{t}$ tabel, maka hipotesis ini ditolak. Hasil tersebut berarti bahwa information quality $\left(\mathrm{X}_{2}\right)$ secara parsial tidak berpengaruh terhadap kepuasan mahasiswa (Y). Dalam hal ini website Universitas Flores belum memberikan informasi yang dibutuhkan oleh mahasiswa tepat pada waktunya. Sehingga menimbulkan rasa ketidakpuasan mahasiswa terhadap website. Penelitian yang lain juga memberikan hasil yang sama, bahwa information quality secara parsial berpengaruh negatif terhadap tingkat kepuasaan pelanggan[11].

Hipotesis keempat memperoleh nilai signifikansi 0,642>0,05, maka hipotesis ini ditolak. Dan juga dilihat dari nilai $\mathrm{t}$ hitung -,094<1,988 t tabel, maka hipotesis ini ditolak. Hasil ini menunjukkan bahwa service interaction $\left(\mathrm{X}_{3}\right)$ secara parsial tidak berpengaruh terhadap kepuasan mahasiswa (Y). Dalam hal ini website Universitas Flores belum memberikan layanan interaksi yang lancar, sehingga berkurangnya kepuasan mahasiswa terhadap website. Penelitian yang lain juga memberikan hasil yang sama, bahwa Service Interaction secara parsial berpengaruh negatif terhadap tingkat kepuasaan pelanggan [11].

\section{Simpulan}

Berdasarkan hasil penelitian, maka dapat disimpulkan:

1. Dari hasil uji koefisien determinasi diperoleh variabel usability $\left(\mathrm{X}_{1}\right)$, information quality $\left(\mathrm{X}_{2}\right)$ dan service interaction $\left(\mathrm{X}_{3}\right)$ menunjukkan bahwa kepuasan pengguna (Y) sebesar $74,8 \%$. Sisanya sebesar $25,2 \%$ dipengaruhi oleh variabel lain yang bukan termasuk dalam model penelitian ini.

2. Ada pengaruh positif secara parsial variabel usability terhadap kepuasan mahasiswa.

3. Tidak ada pengaruh secara parsial variabel information quality terhadap kepuasan mahasiswa. 
4. Tidak ada pengaruh secara parsial variabel service interaction terhadap kepuasan mahasiswa.

\section{DAFTAR PUSTAKA}

[1] Manik, A., Salamah, I., Susanti, E. 2017. Pengaruh Metode Webqual 4.0 Terhadap Kepuasan Pengguna Website Politeknik Negeri Sriwijaya. Jurnal: Elektro Telekomunikasi Terapan (JETT) Bulan Juli. Hal. 477.

[2] Syaifullah dan Soemantri, D.O. 2016. Pengukuran Kualitas Website Menggunakan Metode Webual 4.0. (Studi Kasus: $\quad$ CV. Zamrud Multimedia Network). Jurnal: Rekayasa dan Manajemen Sistem Informasi, Vol. 2, No. 1, Februari. Hal. 20.

[3] M. R. Afsah, M. Adri, and A. Hadi. 2015. Hubungan Efektifitas PSB SMA Online Dan Kinerja Website Terhadap Kepuasan User Diwilayah Dinas Pendidikan Kota Padang. Jurnal: Vokasional Tek. Elektron. Inform., Vol. 3, No. 1.

[4] Aliy Hafiz. 2017. Mengukur kualitas website dengan pendekatan Webqual 4.0 Modifikasi. SEMNAS IIB DARMAJAYA. Lembaga Penelitian, Pengembangan Pembelajaran \&
Pengabdian Kepada Masyarakat. PROSIDING ISSN: 2598-0246 | EISSN: 2598-0238. Hal 443.

[5] Stuart J. Barnes and Richard T. Vidgen. 2002. An Integrative Approach to the Assessment of ECommerce Quality. Journal of Electronic Commerce Research, Vol. 3, No. 3. Page 114.

[6] O. G. Hekhmatyar and D. Supriyadi. 2017. Measurement Satisfaction Information System Quality Service On BSI Using Webqual And CSI Indonesia. Jurnal: on Computer Inf. Technol., Vol. 2, No. 2, pp. 1-6.

[7] Fitria, S. Y., \& SeptiliaArfida, H. Green Cloud Computing Ideas with Security Issues in Setting of Distributed Computing and Cloud Framework.

[8] Arif Masthori, Hanung Adi Nugroho dan Ridi Ferdiana. 2015. Model Pengukuran Kualitas Layanan Website Pemerintah Daerah Menggunakan Metode WebQual. CITEE 2015. Yogyakarta, 15 September 2015. ISSN: 2085-6350 Hal. 102.

[9] Sugiyono. 2011. Metode Penelitian Kuantitatif, Kualitatif dan $R \& D$. Bandung: Alfabeta. Hal. 7, 80, 121.

[10] Yulmaini, Y., Fitria, F., Purba, E., \& Murhadi, M. (2018, January). 
Perancangan Sistem Penjamin Mutu

Dengan Model Capaian Mutu

Berkelanjutan Di Perguruan Tinggi.

In Seminar Nasional Teknologi

Terapan (SNTT) (Vol. 5, pp. 220224).

[11] Arikunto, S. 2013. Dasar-Dasar Evaluasi Pendidikan. Jakarta: Bumi Aksara. Hal. 100.

[12] G. Pramesti. 2014. Kupas Tuntas Data Penelitian dengan SPSS 22. Jakarta: Elex Media Komputindo.

[13] Rusniantoro, R., Kusyanti, A., Rachmadi, A. 2018. Analisis Kualitas Layanan Website XYZ Terhadap Kepuasan Pelanggan Dengan Menggunakan Metode Webqual 4.0. Jurnal: Pengembangan Teknologi Informasi dan Ilmu Komputer. Vol. 2, No. 6, Juni, Hal. 2155. 